\title{
THE LONGEST DAY: DINO CAMPANA AND WALT WHITMAN ACROSS ITALY AND SOUTH AMERICA
}

\section{CATERINA BERNARDINI}

AcCording to Roger Asselineau, Dino Campana (1885-1932), author of the collection Canti Orfici [Orphic Songs] (1914), ${ }^{1}$ was the Italian poet most influenced by Walt Whitman. ${ }^{2}$ Yet, the connections between these poets have not been thoroughly explored nor have critics assessed the implications of Campana's decision to take Leaves of Grass with him in 1907, when he left from Genoa on a ship for Argentina in what would become his transformative journey to South America. ${ }^{3}$

Campana-who has been regarded (and perhaps stereotypically stigmatized) as the Italian poete maudit par excellence, because of his mental illness, ${ }^{4}$ his extravagant and rebellious ways of living, his turbulent social interactions, and the explosive power of his poetic voice-was, with this journey, abandoning himself once again to the roaming life that he deeply loved. But this time the poet was going much farther than on previous sojourns to Paris, or Switzerland, or Mount of La Verna in the Tuscan Apennines, which he loved to climb and get lost in for weeks. This time, Campana was going far away to start a new life in the American hemisphere that he had encountered through the words of Whitman, so it was fitting to bring Leaves of Grass along. With reference to his journeys and experiences in South America, Campana wrote with a mythopoetical and very Whitmanian perception of the American landscape and its imminent potential (especially in the poems "Journey to Montevideo," "Pampas," "A Trolley Ride to America and Back," "Dualism," and in the early draft of "Pampas," "The Fiery Train on the Tawny Pampas"). ${ }^{5}$ These poems can be read as Campana's creative response to Whitman's idea of "America" as the source of an extra-European newness, freedom, and regeneration. For Campana, just as for Whitman, to be a poet in "America" and of "America" meant to move toward modernity and experimentation, to embody a bardic voice that sings a future land of 
equality and democracy, to pursue a personal, social, political, and also creative liberation. ${ }^{6}$

Dino Campana represented a figure of radical alterity within the context of the avant-gardist Italian literary scene of his time-a scene that he repeatedly and desperately tried to enter, but also a scene from which he naturally stood out because of his highly idiosyncratic manner, characterized by a mixture of stylistic innovations and archaisms and by a daring expressionist tone. Although he studied in a prestigious grammar school in Faenza, took part in university cultural life in Bologna, and did his novitiate in the Florentine avant-garde circles that gathered around the literary magazines Lacerba and La Voce and the literary cafè "Giubbe Rosse," Campana refused to adhere to the literary edicts of the Italian futurist avant-gardes that rejected the values of the nineteenth century and that urged the emergence of a new intellectual class ready to make sense of the new industrial society. As a result, Campana was shunned and misunderstood by these circles during his lifetime and also excluded from the mainstream canon after his premature death. His poetic vision remains singular. Labels classifying him as the "Italian Rimbaud" or "visionary poet" have done as much to distort our understanding of his work as have the harsh words of the poet Umberto Saba, who judged Campana to be "crazy, only crazy." We should recognize Campana instead as someone with serious mental issues that had the effect of radicalizing his verse and making it, as poet and critic Edoardo Sanguineti said, "enact a sort of cultural sabotage that led [him] to be completely alone to face things in their nakedness."

Eugenio Montale's description of Campana as "a tramp who read Rimbaud and Whitman" (and, we could add, Verlaine, Baudelaire, Poe, Goethe, and Nietzsche) reminds us that, while spending weeks hiking in the mountains, incarcerated for months here and there, and travelling penniless around Europe and South America, Campana imbibed from the very sources of western poetic modernity, ${ }^{10}$ and one key source was Whitman. Campana read Luigi Gamberale's 1907 translation of Leaves of Grass, and it is reported by the poet Camillo Sbarbaro that Campana "used to walk around Genoa with the book in his hands, as if it was a sort of Bible." ${ }^{\prime 1}$ Although there isn't any 
definite proof, it is likely that Campana also had access to the original: the poet knew English quite well, and he quoted some of Whitman's lines, in his notebooks as well as in his book, in the original English. Campana even chose Whitman to open his first letter of July 1916 to his soon-to-be lover, the intellectual and writer Sibilla Aleramo: "Dear Sibilla, I would like to write to you but I can't. I am terribly bored. Do you know Walt Whitman?"'12 Sibilla, who had written two articles about the American poet, both published in the Nuova Antologia in 1906 and 1908, responded immediately, and with great enthusiasm. ${ }^{13}$ This shared interest in Whitman reflects a developing tendency in the Italian literary scene of the time, in which the American poet was starting to become a central presence in the notebooks, correspondence, and creative work of Italian poets. Even the mere name of the American poet seemed to be generally understood as a signifier of formal innovation and renewal-as well as a sort of love potion.

Campana's fascination with Whitman is revealed in a number of striking analogies between his and Whitman's poetic style. Like Whitman with Leaves of Grass, Campana was almost exclusively concentrated on writing one single, Mallarmean book that he kept on revising, in a continual rewriting process that aimed to produce an open, plural, polysemic work. His mixing of verse and prose was extremely innovative. Not only did he write full poèmes en prose, but he also created heterometrical poems which are the result of his deliberate intermingling of traditional verses with hypermetrical ones. Campana's poetry abandons any strophic partition and plays with iterative parallelisms, obsessive repetitions, and rhythmical dissonance. Like Whitman, Campana had a preference for a nominal style made of catalogues, present participles, gerunds, juxtaposed adverbs and adjectives, as well as anaphoras and homeoteleuta (or near rhymes). Like Whitman, he built a multilingual text by using English, French, German, vernacular, and dialectal forms, but also by mixing classical, erudite terms and archaisms with popular and technical ones. Like Whitman, he was "afoot with [his] vision," carrying out an initiatory journey in order to look for a point of pure, electric (an adjective that Campana, like Whitman, used profusely) contact with nature and with its cosmic cycles, battling against common certainties and 
assumed cultural and social clichés, trying to catch the shapeless flow of reality at its core source, in which past, present, and future could converge.

Another significant connection between Whitman and Campana involves Enrico Nencioni, the 1880s Italian critic who helped circulate Whitman's poetry in Italy and who had argued that the American's poems were "veri canti orfici senza tradizione," "real, unprecedented orphic songs." "Significantly, Campana entitled his 1914 book Orphic Songs. This striking combination of a Whitmanian and an Orphic lineage extends to the present: contemporary writers Giuseppe Conte and Roberto Mussapi, for example, both define themselves as "neoorphic" poets as well as direct descendants of Campana, and, at the same time, both have translated Whitman's poetry, written critical pieces about it, and are clearly inspired by Whitman's work. ${ }^{15} \mathrm{~W}$ ithin the twentieth-century Italian literary scene, Campana's work functions, then, not only as an inspirational text per se, but also as an important mediation site for the diffusion and appreciation of Whitman's poetry.

Campana quoted passages from Leaves both in his notebooks (including passages from "So Long," "To a Locomotive, in Winter," "Bivouac on a Mountain Side," and "Whispers of Heavenly Death") and in Orphic Songs itself. Campana's original manuscript for what would eventually become Orphic Songs was initially called Il più lungo giorno (The Longest Day) ", presumably a quote from line 18 of Whitman's "Salut au Monde" ("Within me is the longest day") ". And the epigraph of Orphic Songs is an adaptation from Section 34 of the deathbed edition version of "Song of Myself"; it reads: "they were all torn and cover'd with the boy's blood," instead of the original "the three were all torn and covered with the boy's blood." Intriguingly, in two different versions of his work, by placing the epigraph once at the beginning and once at the ending of the book, Campana started and finished in Whitman's name. In a 1916 letter, the poet told the critic Emilio Cecchi to consider these words of the epigraph, which he acknowledged to be taken from Leaves of Grass, as the most relevant words in the whole book. ${ }^{18}$ This acknowledgment has raised the attention of critic Francesca Roberta Seaman. In her 2007 dissertation on Campana, which offers 
a psychoanalytical interpretation of recurrent figures and chromatic images that reveal the centrality of the sense of loss and despair in Campana's writing, Seaman repeatedly argues that the epigraph taken from Whitman stands within Campana's collection as an emblem of the existential tragedy inherent to his poetry. ${ }^{19}$ But in Campana's work, anguish is offset by many luminous moments of serenity and optimism. And even the epigraph, although it contains a dramatic image, signifies, as indicated by Roberto Coppini, ${ }^{20}$ more than the actual suffering that Campana endured in his life and reflected upon in his writing. Rather, it evokes Campana's perception of Whitman's poetry as a strong, energizing encouragement for him to break with past formal rules, legitimate his distancing himself from them, and declare his almost heroic, creative alterity, his absolute faith in a new, independent poetry - a faith that could even result in martyrdom and bloodshed. In this sense, Campana's journey to South America, accompanied by Whitman's book, should be read as a literal enactment of a Nietzschean and messianic quest for a poetical territory of revolt and regeneration.

Campana's three-week journey across the ocean was on a ship bound to Buenos Aires, Argentina through Montevideo, the coastal capital of Uruguay. The central image of his poem "Journey to Montevideo" is that of a physical and metaphysical, almost Dantean, "crossing" of the ocean, reminiscent of Whitman's "Crossing Brooklyn Ferry."21 Here the lyrical "I" remembers what he saw when approaching the new continent. There are many affinities with Section 3 of "Crossing Brooklyn Ferry," mostly due to a similar insistence on evoking the visual experience: "I saw from the deck of the ship / . . We saw rising in the enchanted light / . . And I saw like whirling" (LB 103; 105). ${ }^{22}$ Analogous images of birds floating in the sunset sky, lit by the last sun beams, occupy the central part of both poems: in Campana's,

The pale-blue evening languished on the sea:

From time to time the golden silences of wings

Also crossed slowly in the deepening blue...

Distant tinged with various colors

From the most distant silences (LB 103; ellipsis in original ${ }^{23}$ 
And, in Whitman's:

Watched the Twelfth month sea-gulls, saw them high in the air floating with motionless wings, oscillating their bodies,

Saw how the glistening yellow lit up parts of their bodies and left the rest in strong shadow,

Saw the slow-wheeling circles and the gradual edging toward the south ${ }^{24}$

The vivid prefiguration of the New World is in Campana's poem embodied by ". . . a bronze-colored girl / Of the new race appeared to us / Eyes shining, and clothes in the wind!" (LB 105) ${ }^{25}$ which brings to mind the women of Whitman's "A Woman Waits for Me": "They are tann'd in the face by shining suns and blowing winds."26

The connections are not only thematic and imagistic. As in Whitman, the use of flowing free verse and of iterated gerunds (highly unusual in Italian poetry) — “celando" (hiding), "varcando" (crossing), "battendo" (beating) — allows Campana to create a vision that dwells in a mythical time between real and unreal, old and new, personal and public, past and present. "Journey to Montevideo," like "Crossing Brooklyn Ferry," aims at seizing an eternal moment of stillness and presence from the incessant whirlpool of life. And it is also a Ulyssean journey (notice the "shipwrecked hearts" of line 16 [LB 103] ${ }^{27}$ ) toward a savage shore and an endless prairie, toward what's unknown, primordial, archaic, old and new at the same time.

It is a journey toward an ideal reintegration of the self within a profound, ahistorical, universal harmony that the lyrical I of the poème en prose "Pampas" seems to have reached, having left behind the cultural preconditioning baggage and restraints of old Europe. ${ }^{28}$ It is significant that Campana finally chose the poème en prose structure here, having first tried to compose the poem in hendecasyllables as one can see in his 1911-1912 notebook. ${ }^{29}$ The lyrical prose of the final version of "Pampas" is characterized by a radical use of minimal punctuation, except for a number of colons, which are in many cases followed by relative pronouns, as in the following quotation:

My thoughts wavered: my memories drifted by in quick succession: that delightfully seemed to submerge and reappear in the distance now and then lucidly beyond the human, as if through a deep mysterious echo, within the infinite majesty 
of nature (LB 149)..$^{30}$

This is an unusual, unconventional stylistic choice that produces a sort of rhythmical shock, and that also seems to be an odd re-creation of line breaks and enjambments within a prose structure. It is this peculiar structure that allows Campana to experiment with free verse and the mingling of poetry and prose, while he tends to stay attached to more traditional modes of versification in other poems, such as "Pound the Ground" or "La Petite Promenade du Poète."

"Pampas" is full of Whitmanian echoes, beginning with the symbol of the Argentinian grassy prairie ${ }^{31}$ and the image of a bivouac under the stars. The Italian word used by Campana, "bivacco," is the translation of "bivouac," a word of French origin that Whitman used in "Bivouac on a Mountain Side":

Stretched on the virgin grass, facing the strange constellations, I was gradually giving in to the mysterious play of their arabesques, delightfully rocked by the muffled noises of the camp. . . . Slowly gradually I was rising to the universal illusion: from the depths of my being and of the earth, across the paths of the sky I followed mankind's adventurous journey toward happiness through the centuries. Ideas shone with the purest starlight ... A star flowing in magnificent flight marked in glorious line the end of a course of history (LB 149). ${ }^{32}$

The key symbolic elements of this poème en prose are stars and constellations that seem to be comets indicating a new path for mankind. Here, while "for a wonderful instant the eternal destinies alternating immutably in time and space" (LB 151), ${ }^{33}$ the moonbeams illuminate the prairie enough to see "an army that hurled throngs of horsemen with their lances couched, sharp-pointed and gleaming" (LB 151). ${ }^{34}$ This description resembles "The shadowy forms of men and horses, looming, large-sized, flickering, / And over all the sky - the sky! Far, far out of reach, studded, breaking out, the eternal stars" of "Bivouac on a Mountain Side." ${ }^{" 35}$ But, for Campana, the army is made of "Indians dead and alive" who seem to be offered, in this ahistorical dimension of primordial freedom, the possibility to "reconquer their dominion of freedom. The grasses bent in a light wail at the wind of their passage" (LB 151). ${ }^{36}$ The grass here, as in Whitman, is a polyseme standing for 
nature, democracy, connection with the past, and renewal of life. But Campana's use of the word "illusion" is also highly significant. The Italian poet is aware that he will have to go back to Europe, and, most of all, he is aware that even the "new" land of South America bears the signs of history and human violence and injustice. But the dream goes on for a moment, and the lyrical "I" reaches out for cosmic forces: ${ }^{37}$

I was on the speeding train ... the Pampas racing toward me to take me into their mystery ... Where was I? I was standing: I was standing: on the pampas in the rushing winds, standing on the pampas that were flying toward me: to take me into their mystery! A new sun would greet me in the morning! Was I speeding among the Indian tribes? Or was it death? Or was it life? . . . Stretching out on the iron flooring, concentrating on the strange constellation fleeing among light silver veils: and my whole life so similar to that blind fantastic irresistible rush coming back in bitter vehement streams. ... The light of the now impassive stars was more mysterious on the infinitely deserted earth: a vaster homeland had destiny given us: a sweeter natural warmth was in the mystery of the savage good earth (LB 151; 153)..$^{38}$

The poetic persona is represented on a train completely absorbed by the rush, and the hope, of finding a "new sun," a "vaster homeland." 39 The 1911-1912 draft of "Pampas" (mentioned above), "The Fiery Train on the Tawny Pampas," is significantly indicative of a Whitmanian isomorphism of the lyrical "I," the continent, and the book: "The fiery train on the tawny pampas / Always ran its triumphant race / And vertiginously upset / The virginal infinite endlessly / Kissed me on the face and the grotesque and enormous / Continent changed its posture - immediately endlessly / So my book: and here it: / Here it comes on crippled feet / My sonnet a salute to you / Accept it kindly . .." (ILS 129). Campana's words are reminiscent of Whitman here, both in his sensual, even carnal, embrace of the continent and in his ultimate entrusting of his book to his readers.

"Pampas," as noted by critic Piero Bigongiari, seems to have a "genetic function, with its labor pains, propitiating the birth of the new man" (377). But the "new man being born" is a "free man" at the end of the text, a man finally born to freedom in the American space: 
And it was then that in my final torpor I felt with delight the new man being born: man being born reconciled with nature, ineffably sweet and frightening: delightfully and proudly vital juices being born to the depths of being: flowing from the depths of the earth: the sky like the earth high above, mysterious, pure, deserted of shadows, infinite. I had stood up. Under the impassive stars, on the earth infinitely deserted and mysterious, from his tent free man extended his arms toward the infinite sky undefiled by the shadow of Any God (LB 153; 155). ${ }^{41}$

This vitalistic, Nietzschean, mythical regeneration, far from the chains of tradition and morals - and instead, blessed by a reconciliation with nature - contains the quintessence of Campana's perception of "America," and with it, of the renewed, innovative, modern poetry that Italy was still struggling to achieve. Campana's stylistic experimentation here becomes vehement, in its feverishly appositive style, reinforced by the use of iterated colons that disconnect the lines only to give way to semantic repetitions that have the opposite effect-a rush toward the craved conclusion.

Carlo Bo and Gabriel Cacho Millet, two critics who have noted (if only briefly) the fact that Campana brought Leaves of Grass with him in his journey to Argentina, have rightly noted that Whitman's poetry served as a cherished companion for this journey, but they argue that Leaves of Grass did not serve as Campana's guide or model. ${ }^{42}$ In contrast, what interests me is the evident closeness of Whitman's and Campana's utopian and mythopoetical perception of American possibility: both poets share the common European myth of "America" as the land of the barbaric, ${ }^{43}$ the new, the tabula rasa both in political and poetical terms.

The critic Silvio Ramat offers an attractive hypothesis: playing with the word "chimera" (as defined by Bonaffini, a "hauntingly complex apparition, a fleeting sign of metaphysical opening, present throughout Campana's work and prefiguring the poetic mission itself") ${ }^{44}$ he anagrammatizes it as "America." For Ramat, Campana's true object of desire is "America," "the new continent of poetry: the most modern and most primordial one." ${ }^{45}$ And yet, if "America" does help Campana to find contact with personal freedom and poetic inspiration, innovative diction and experimental strength, he chooses 
not to root his poetry exclusively in such a real and ideal territory: he wants to be able to create an authentically transnational poetry. As he writes in "Dualism," Argentina has been a place where "for a moment my life came into contact again with the forces of the cosmos" ${ }^{246}$ (LB 127), but he has to go back "toward the calm oases of old Europe's sensibility" (LB 129; it is no accident that, in several poems about this journey, he insists on the idea of a "round trip"). The secret, as the title "Dualism" implies and the poem makes clear, is to be able to profit from both, and perhaps to understand that a separation does not even exist - it is artificial - and that Europe and America are inevitably interconnected. Another significant poem in this transnational sense is "Fantasy on a Painting by Ardengo Soffici," where the work of the Florentine critic and artist is intrasemiotically translated into poetry by Campana within an American setting that resonates with tango:

Face, anatomical zigzag that dims

The grim passion of an old moon

That watches hanging from the ceiling

In a tavern American

Café chantant: the red speed

Of lights rope-dancer that tangoes

Ashen Spanish girl

Hysterical with lights dissolves in tango:

That watches in the American

Café chantant:

On the hammered piano three

Red flames lit up all by themselves (LB 109). ${ }^{48}$

Campana saw Soffici's painting at a Futurist exposition in Florence, at the Libreria Gonnelli, in November 1913. The painting, called Compenetrazione di piani plastici. Tarantella dei pederasti (later destroyed by the artist), was abstract and made no explicit reference to an American and/or Argentinian setting, and yet, as noted by critic Gabriel Cacho Millet, ${ }^{49}$ it reminded Campana of a dance he saw in the Argentinian café chantant where he worked as a pianist. Thus, the aesthetic perception of a work of art produced in the context of Italian Futurism and, more largely, of European avant-gardes of the beginning of the twentieth century, fused with the poet's experience in another 
cultural context and became a new, independent, and yet always interconnected, transcultural poem. I think this exemplifies how Campana's poetry should be read in relation to Whitman's work and to his idea of "America." More generally, this reminds us of the polyvocal, intertextual dialogue that texts constantly, though sometimes more and sometimes less explicitly, contain and enact. In this specific case, it would be possible to extend our consideration to include Ruben Darío's or Edoardo Sanguineti's poems about their visions of "America," in this dialogue between Whitman and Campana. Perhaps such mediating critical acts are finally what can make us enjoy a "longest day" under the extended, double light with which we can see as both European Americans and American Europeans.

\section{University of Nebraska-Lincoln E University of Macerata, Italy caterina.bernardini@gmail.com}

\section{NOTES}

1 This is the only volume of poetry published by Campana (the book was released in 1914 in his hometown, Marradi, by the printmaker Bruno Ravagli). But there are also a few other poems that were published separately, in periodicals, and also various drafts and miscellaneous materials that came to light after the writer's death. Additional materials have been combined with the original 1914 bulk of poems already in the second edition, published by Vallecchi in 1928 without the writer's authorization, and have often been used for later editions. (This is why editions of Campana's work after 1914 are usually entitled Canti Orfici e altre poesie, i.e. Orphic Songs and Other Poems.) In this essay, I will mostly concentrate on poems that were already included in the 1914 edition, but I will indicate in the notes when the text I am using was not contained in the original volume.

2 See Roger Asselineau, "Whitman in Italy," in Walt Whitman and the World, ed. Gay Wilson Allen and Ed Folsom (Iowa City: University of Iowa Press, 1995), 273.

3 According to Gabriel Cacho Millet, the source of this information was Campana's uncle, who had accompanied the poet to the harbor when leaving for South America. See Millet, "L'ultimo dei Campana," L'informatore librario 8, no. 5 (Maggio 1978). Campana's journey to South America has been questioned, especially by the Italian poet Giuseppe Ungaretti, who even talked about "mythomania" because of an apparent lack of official documents that could prove that the journey did take place (see Piero Bigongiari, Capitoli di una storia della poesia italiana [Firenze: Le Monnier, 1968], 359). While scholars have now agreed about the fact 
that the journey did take place, also thanks to Caroline Mezey's retrieval of the document that proves that Campana was granted a passport in September 1907 (see her "Documenti inediti per la biografia di Dino Campana [1906-1913]" Studie problemi di critica testuale 32 [April 1986]), there is still no conclusive proof about the exact dates and length of the journey. While in the above quoted article Millet indicates February 1908 as the date in which Campana left Genoa, he later hypothesized that the poet might have left already in the fall of 1907. See Millet's Dino Campana sperso per il mondo: autografi sparsi, 1906-1918. (Firenze: L.S. Olschki, 2000), 32-35; "Introduction" to Il cantore vagabondo. Dino Campana (Milano: Corriere della sera, 2012), available online at campanadino.it. See also Gianni Turchetta, Dino Campana: biografia di un poeta. (Milano: Feltrinelli, 2013), 78-79. According to Millet and Turchetta, Campana spent about one year in South America-mostly in Montevideo and Buenos Aires-as the first traces of him being back in Europe correspond to February/March 1909. In South America he worked on railway embankments, but he was also a miner, a fireman, and a juggler. At times, he just wandered like a nomad. At other times, he played the piano in brothels, stoked coal on a ship, and worked in a rifle range.

4 The poet was diagnosed early in his life with dementia praecox and neurasthenia and was often hospitalized in psychiatric institutions. He spent the last fourteen years of his life (1918-1932) in a mental institution.

5 All the English translations used in this essay when quoting Campana are by Luigi Bonaffini, as they appear in Dino Campana, Canti orfici e altre poesie. Orphic Songs and Other Poems, trans. and introduction by Luigi Bonaffini (New York: Peter Lang, 1991). The only exception is for the early draft of "Pampas," "The Fiery Train on the Tawny Pampas," which I took from Dino Campana: Orphic Songs, trans. I. L. Salomon, (New York: October House, 1968), 129. When quoting from these translations, I will abbreviate Bonaffini's translation as LB and Salomon's as ILS, within the references in parenthesis. The original passages in Italian, which are offered in endnotes with page references, are all taken from Dino Campana, Canti Orfici e altre poesie (Torino: Einaudi, 2003), except for "Nella pampa giallastra il treno ardente" ("The Fiery Train on the Tawny Pampas") which I took from Dino Campana. Inediti, ed. Enrico Falqui. (Firenze: Vallecchi, 1942), 139-140. It could be argued that the translations into English significantly modified the tone of the original. I do not think this is the case, as both Bonaffini and Salomon have rendered Campana as accurately as possible. The iterations and gerunds and the nominal style are clearly present in the original, as one could notice by looking at the Italian. Perhaps the translators are not always successful at accomplishing the extremely difficult task of rendering the archaic terms and dignified nuances that Campana sometimes uses, but they do faithfully render in English the rhythm, the syntactical oddities, the imagery, and the overall tone of the original.

6 Throughout this essay, I place in quotation marks the word "America" when I refer to the idea or myth of "America" as opposed to the reality of North and 
South America.

7 My translation. Saba's words are quoted by Pier Vincenzo Mengaldo in Poeti italiani del Novecento (Milano: Il Saggiatore, 1978), 277.

8 See Edoardo Sanguineti, Poesia italiana del Novecento (Torino: Einaudi, 1969), 1:liv-lv.

9 See Eugenio Montale, "Sulla poesia di Campana," L'Italia che scrive 25 (September-October 1942). Montale is one of the few critics who understood the relevance of Whitman's work for Campana's poetry. He wrote, for example, that "there is a certain Italian poetry that goes from the best followers of D'Annunzio (like Adolfo De Bosis) to the early Futurism and Campana, which could not be explained without recurring to names such as Poe and Walt Whitman" (my translation). See Eugenio Montale, Il secondo mestiere. Prose 1920-1979, Vol. 2 (Milano: Mondadori, 2006), 2033-2034.

10 References to Campana's readings of European and American writers (including Whitman) of the end of the nineteenth century and beginning of the twentieth are made in Giovanni Bonalumi, Cultura e poesia di Campana (Firenze: Vallecchi, 1953); Cesare Galimberti, Sulla formazione di Campana (Milano: Mursia, 1964); Mario Costanzo, Critica e poetica del primo Novecento. Boine, Campana, Sbarbaro, Rebora (Roma: Edizioni di Storia e Filosofia, 1969); O poesia tu più non tornerai. Campana moderno, ed. Marcello Verdenelli (Macerata: Quodlibet, 2003); Dino Campana: una poesia europea musicale colorita (Giornate di studio, Università degli Studi di Macerata, 12-13 maggio 2005), ed. Marcello Verdenelli (Macerata: Eum, 2007).

11 See Renato Martinoni, "Introduzione" in Dino Campana, Canti Orfici e altre poesie (Torino: Einaudi, 2003), xix; Carlo Pariani, Vite non romanzate di Dino Campana scrittore e di Evaristo Boncinelli scultore (Firenze: Vallecchi, 1938), 56.

12 See Sibilla Aleramo e Dino Campana: Un viaggio chiamato amore. Lettere 19161918, ed. Bruna Conti (Milano: Feltrinelli, 2000), 43.

13 Aleramo's admiration for Whitman's poetry, which began in 1899 or 1900 when she first read Leaves of Grass and resulted in the two articles she published in the Nuova Antologia in 1906 and 1908, was revitalized in Paris during the winter of 1913-1914, when Aleramo met Léon Bazalgette, translator of Whitman's poetry into French. The two spent time together within the circle of the literary magazine Mercure de France, in which artists like Paul Claudel, Paul Valéry, Émile Verhaeren and others, took part. On this, see Anna Folli's introduction to Orsa Minore. Note di taccuino e altre ancora (Milano: Feltrinelli, 2002), 23.

14 See Enrico Nencioni, "Walt Whitman," La Fanfulla della Domenica 1 (December 7, 1879). My translation. It is quite plausible that Campana had read Nencioni's essay, even if the critic wrote it when Campana had not yet been born. Campana was an extremely avid reader of both foreign literatures, of which Nencioni had 
been a major divulgator in Italy, and of the Italian poetry that slightly preceded him and that had taken Nencioni's critical views into great account. Nencioni's work was in fact highly influential on Italian late nineteenth and early twentieth century literary scene, and writers like Gabriele D'Annunzio and Giosuè Carducci were among his greatest admirers. See Le più belle pagine di Enrico Nencioni, ed. Bruno Cicognani (Milano: Garzanti, 1943); Benedetto Croce. La letteratura della nuova Itali, Vol. 2 (Bari: Laterza, 1943), 116-124.

15 See Maria Antonietta Grignani, "Momenti della ricezione di Campana," in Dino Campana alla fine del secolo. Atti del convegno di Faenza, 15-16 maggio 1997, ed. Anna Rosa Gentilini (Bologna: Il Mulino, 1999), 169-188; and also Roberto Mussapi's critical notes on Campana, included in Il centro e l'orizzonte. La poesia in Campana, Onofri, Luzi, Caproni, Bigongiari (Milano: Jaca Book, 1985).

16 Campana gave this manuscript to the poet and critic Ardengo Soffici in 1913; it was lost for nearly sixty years, thus forcing Campana to reconceive what later became Orphic Songs.

17 It must be noted that a few Campana scholars suggest-without providing any conclusive proof-that the title "The Longest Day" might derive from Gabriele D'Annunzio's 1910 novel Forse che si, forse che no, in which the solstice of summer, "the longest day," appears as an important leitmotif. [See Antonio Corsaro, "La prosa narrativa di D’Annunzio nell'opera di Dino Campana". In Bibliografia campaniana (1914-1985), ed. Marcello Verdenelli and Antonio Corsaro (Ravenna: Longo Editore, 1985) 95; Simona Costa. "Dino Campana: un rendiconto dannunziano." Paragone 330 (1997), 79; in Dino Campana, Il più lungo giorno, ed. Stefano Giovannuzzi (Firenze: Le Cáriti, 2004), 23-24.] While it is not certain that such a connection exists, it should be said that D'Annunzio himself admired and often imitated Whitman, and it is therefore not unlikely that the very image of the longest day in D'Annunzio's novel may have also been borrowed from Whitman's "Salut au Monde!".

18 See Cesare Galimberti, Dino Campana (Milano: Mursia, 1967), 47.

19 See Francesca Roberta Seaman, "A Poetry of Loss: Love, History and Mental Illness in the Writings of Dino Campana." Ph.D. Dissertation, Yale University, 2007, 1. Seaman argues that "Whitman's verse could stand as an epigraph to all of Campana's poetic work," but her use of the word "verse" instead of "line" is misleading. Seaman's remark seems to encompass all Whitman's poetry, but in fact her dissertation focuses on the dark implications evoked by a single line (the one from "Song of Myself," adapted and used as epigraph by Campana) and does not venture into any larger comparative evaluation of the work of the two poets.

20 See Roberto Coppini, "Su Dino Campana". Revue des Langues Romanes 89 (1985), 135-156. In this essay, Coppini argues that the epigraph adapted from Whitman has not been taken into sufficient consideration by critics, but that it represents a crucial key to read Campana's work. Coppini shifts his attention away 
from the possible biographical reference that the citation might seem to make, to Campana's will to declare, in the name of and through the words of Whitman, his break with past literary traditions and his difference from the futurist group. Coppini's essay is also very useful for a larger contextualization of the influence of Whitman on Italian poets of Campana's generation.

21 This is also a recurrent image in other poems by Campana as "Ship's Voyage," "Humanity Teeming on the Spur," and "Genoa" (while the latter poem was part of the original 1914 Orphic Song, the first two poems were first published in the 1942 Inediti and often included in later editions of Orphic Songs and Other Poems).

22 Original: "Io vidi dal ponte della nave / . . . Noi vedemmo sorgere nella luce incantata / . . E vidi come cavalle" $(56,57)$.

23 Original: "Illanguidiva la sera celeste sul mare: / Pure i dorati silenzii ad ora ad ora dell'ale: / Varcaron lentamente in un azzurreggiare... [ellipsis in orignal] / Lontani tinti dei varii colori / Dai più lontani silenzii" (56).

24 See Walt Whitman, "Crossing Brooklyn Ferry" in LG 1891-1892, 130. Available on the Walt Whitman Archive (www.whitmanarchive.org).

25 Original: “. . . bronzina / Una fanciulla della razza nuova, / Occhi lucenti e le vesti al vento!” (57).

26 See Walt Whitman, "A Woman Waits for Me" in $L G$ 1891-1892, 88.

27 Original: "naufraghi cuori" (56).

28 On this, see also Silvano Salvadori's "Una Vicinanza di Temi e di Testi fra Dino Campana e Walt Whitman: Pampa.” Available on campanadino.it.

29 Piero Bigongiari discusses this draft in Capitoli di una storia della poesia italiana (Firenze: Felice Le Monnier, 1968), 376. The draft was first published, with the title of "Nella pampa giallastra il treno ardente" ("The Fiery Train on the Tawny Pampas") in the volume entitled Inediti (i.e. Unpublished Materials), published in 1942 by Vallecchi and edited by Enrico Falqui. I discuss part of this draft on page 11.

30 Original: "I miei pensieri fluttuavano: si susseguivano i miei ricordi: che deliziosamente sembravano sommergersi per riapparire a tratti lucidamente trasumanati in distanza, come per un'eco profonda e misteriosa, dentro l'infinita maestà della natura" (93).

31 The "pampas" are vast fertile lowlands that occupy part of the territories of Argentina, Uruguay, and Brazil.

32 Original: "Gettato sull'erba vergine, in faccia alle strane costellazioni io mi andavo abbandonando tutto ai misteriosi giuochi dei loro arabeschi, cullato deliziosamente dai rumori attutiti dal bivacco. . . . Lentamente gradatamente io assurgevo all'illusione universale: dalle profondità del mio essere e della terra io ribattevo per le vie del cielo il cammino avventuroso degli uomini verso la felicità a traverso i secoli. Le idee brillavano della più pura luce stellare. . . . Una stella fluente in 
corsa magnifica segnava in linea gloriosa la fine di un corso di storia" $(93,94)$.

33 Original: "per un meraviglioso attimo immutabilmente nel tempo e nello spazio alternandosi i destini eterni” (94).

34 Original: "un esercito che lanciava torme di cavalieri colle lancie in resta, acutissime lucenti" (94).

35 Walt Whitman, "Bivouac on a Mountain Side" in LG 1891-1892, 235.

36 Original: "alla riconquista del loro dominio di libertà in lancio fulmineo. Le erbe piegavano in gemito leggero al vento del loro passaggio" (94).

37 As he explicitly does in another poem set in Argentina, "Dualism."

38 Original: "Ero sul treno in corsa: . . . la Pampa che mi correva incontro per prendermi nel suo mistero: . . . Dov'ero? Io ero in piedi: Io ero in piedi: sulla pampa nella corsa dei venti, in piedi sulla pampa che mi volava incontro: per prendermi nel suo mistero! Un nuovo sole mi avrebbe salutato al mattino! Io correvo tra le tribù indiane? Od era la morte? Od era la vita? . . . Lo stendersi sul piatto di ferro, il concentrarsi nelle strane costellazioni fuggenti tra lievi veli argentei: e tutta la mia vita tanto simile a quella corsa cieca fantastica infrenabile che mi tornava alla mente in flutti amari e veementi. . . . La luce delle stelle ora impassibili era più misteriosa sulla terra infinitamente deserta: una più vasta patria il destino ci aveva dato: un più dolce calor naturale era nel mistero della terra selvaggia e buona" $(94,95)$.

39 Note how the train is not only symbolic of modernity and of an oneiric journey, but presumably is also a reference to Campana's actual work in Argentina as a peón de vía, a railroad worker.

40 For a history of the draft, see note 29. Original: "Nella pampa giallastra il treno ardente / Correva sempre in corsa vittoriosa / E travolto vertiginosamente / Il vergine infinito, senza posa / Mi baciava sul viso, e il continente / Grottesco e enorme cambiava la posa - immantinente, senza posa / Così il mio libro: ed ecco che: / Ecco che viene colle gambe storte / Il mio sonetto a voi per salutare / Accettatelo bene" (Inediti 139).

41 Original: " $\mathrm{E}$ allora fu che nel mio intorpidimento finale io sentii con delizia l'uomo nuovo nascere: l'uomo nascere riconciliato colla natura ineffabilmente dolce e terribile: deliziosamente e orgogliosamente succhi vitali nascere alle profondità dell'essere: fluire dalla profondità della terra: il cielo come la terra in alto, misterioso, puro, deserto dall'ombra, infinito. Mi ero alzato. Sotto le stelle impassibili, sulla terra infinitamente deserta e misteriosa, dalla sua tenda l'uomo libero tendeva le braccia al cielo infinito non deturpato dall'ombra di Nessun Dio” (95, 96).

42 See Carlo Bo, "Nel nome di Campana," Dino Campana oggi. Atti del convegno, Firenze 18-19 marzo 1973 (Firenze: Vallecchi, 1973), 14; Gabriel Cacho Millet, Dino Campana sperso per il mondo. Autografi sparsi 1906-1918 (Firenze: L. S. Olschki, 2000), 36. 
43 The word "barbaric" appears in both Campana's and Whitman's work, and it is undoubtedly a crucial word for the reception of Whitman in Italy, starting from Giovanni Papini's essay of 1908, in which the very influential critic observed: "We must become barbarians again - maybe even a bit boorish - if we want to rediscover poetry. If Whitman did not teach us at least this, then all the translations and all the talking that has been made about him were completely useless" (my translation). See Giovanni Papini, "Walt Whitman," La Nuova Antologia, 1908 (June 16), 696-711.

44 See Luigi Bonaffini, "Introduction" in Canti Orfici e Altre Poesie. Orphic Songs and Other Poems (New York: Peter Lang, 1991), xxxv.

45 See Silvio Ramat, "Qualche nota per 'La Chimera'," in Dino Campana alla fine del secolo, ed.. Anna Rosa Gentilini (Bologna: Il Mulino, 1999), 38.

46 Original: "a mia vita ritrovò un istante il contatto colle forze del cosmo" (73).

47 Original: "verso le calme oasi della sensibilità della vecchia Europa" (74).

48 Original: "Faccia, zig zag anatomico che oscura / La passione torva di una vecchia luna / Che guarda sospesa al soffitto / In una taverna café chantant d'America: la rossa velocità / Di luci funambola che tanga / Spagnola cinerina / Isterica in tango di luci si disfà: / Che guarda nel café chantant / D’America: / Sul piano martellato tre / Fiammelle rosse si sono accese da sé" (58).

49 See Gabriel Cacho Millet, Dino Campana sperso per il mondo. Autografi sparsi 1906-1908 (Firenze: Olschki, 2000), 40. 